\title{
Annals of Glaciology
}

Papers from the 2005 International Symposium on High-elevation Glaciers and Climate Records held in Lanzhou, China, on 5-9 September, 2005 


\title{
VOLUME 43
}

\section{EDITORS}

Chief Editors

Ellen Mosley-Thompson Lonnie G. Thompson

Associate Editors

\author{
Vladimir Aizen \\ Michael Bender \\ Henry Brecher \\ DeWayne Cecil \\ Mary Davis
}

Lewis Owen

Jiawen Ren

Margit Schwikowski

Mathias Vuille

Ninglian Wang

Tracy Mashiotta

\section{INTERNATIONAL GLACIOLOGICAL SOCIETY}

$\begin{array}{ll}\text { President } & \text { Atsumu Ohmura } \\ \text { Vice-Presidents } & \text { lan Allison } \\ & \text { Eric Wolff } \\ & \text { Eric Brun } \\ \text { Treasurer } & \text { John Heap } \\ \text { Secretary General } & \text { Magnús Már Magnússon }\end{array}$

\section{IN-HOUSE PRODUCTION}

Production Manager

Production Assistant

Reference Editor

House Editor

Publishing Assistant

Typesetter/Programmer
Christine Butler

Craig Baxter

Rowena Baxter

Ken Moxham

Ann Leeding

Ali Woollatt

Cover illustration The drill site on Dasuopu in the Himalaya with Xixiabangma in the background. This shows the site of the highest ice core ever collected $(7200 \mathrm{~m}$ above sea level) and is located in the central Himalaya.

Photo from Lonnie G. Thompson. 


\section{Annals of Glaciology}

Papers from the 2005 International Symposium on High-elevation Glaciers and Climate Records held in Lanzhou, China, on 5-9 September, 2005

Published by

the International Glaciological Society,

Cambridge, UK 
The Annals of Glaciology contains peer-reviewed, edited papers from IGS-sponsored symposia. Papers in this publication are indexed in the Science Citation Index ${ }^{\mathbb{R}}$, Science Citation Index-Expanded (also known as Sci-Search ${ }^{\circledR}$ ), and ISI ${ }^{\circledR}$ Alerting services.

The accurary of references in the text and lists is the responsibility of the authors, to whom queries should be addressed.

The Annals of Glaciology is available online. Subscribers wishing to access the online journal should go to www.ingentaselect.com/register.htm and follow the online instructions. For subscription information contact igsoc@igsoc.com.

ISSN 0260-3055

ISSN 1727-5644 (Online)

ISBN 0-946417 385

(C) International Glaciological Society 2006

All rights reserved; no part of this publication may be reproduced, stored or retrieved in any form or by any means, electronic, mechanical, photocopying, recording, or otherwise without the prior written permission of the International Glaciological Society (IGS), except as stated below.

The Annals of Glaciology is registered with the Publishers Licensing Society Limited. Consent is given for single copies of single articles to be made for private study or research, or for the personal or internal use of specific clients, provided the appropriate fee is paid to The Copyright Licensing Agency, 90 Tottenham Court Road, London, W1P OLP (Fax: 020-76315555; e-mail: info@cla.co.uk). Illustrations and short extracts from the text of individual contributions may be made provided the source is acknowledged and permission is granted by the authors and the IGS. The IGS hereby gives permission for abstracts of articles in this issue to be reprinted by abstracting journals. 